\title{
EFEKTIVITAS METODE PEMBELAJARAN PENDIDIKAN JASMANI PLAY-TEACH-PLAY TERHADAP PENINGKATAN KEBUGARAN SISWA SEKOLAH DASAR
}

\author{
Rahmat Permana \\ Universitas Muhammadiyah Tasikmalaya \\ Jl. Tamansari Km.2,5 Tamansari Kota Tasikmalaya \\ Email: rahmat.pgsd@umtas.ac.id \\ Feida Noorlaila Istiadah \\ Universitas Muhammadiyah Tasikmalaya \\ Jl. Tamansari Km.2,5 Tamansari Kota Tasikmalaya \\ Email: feida@umtas.ac.id
}

\begin{abstract}
Abstrak
Permasalahan dalam penelitian ini ialah rendahya kebugaran siswa Sekolah Dasar (SD). Masalah tersebut karena tidak adanya suatu metode mengajar olahraga yang sesuai dengan perkembangan dan karakteristik siswa SD. Karakteristik anak SD cenderung tidak menyukai penjelasan teori dan konsep dari guru pendidikan jasmani, mereka ingin pembelajaran yang menyenangkan. Pembelajaran yang menyenangkan bisa melalui metode permainan (play) sehingga anak tertarik untuk terus aktif bergerak. Tujuan jangka panjang dari penelitian ini untuk menerapkan metode-metode permainan dalam pembelajaran olahraga di Sekolah Dasar yang menunjang proses pembelajaran olahraga yang optimal terhadap peningkatan kebugaran. Sedangkan tujuan khusus ialah memperoleh gambaran nyata tentang keefektivan metode playteach-play (bermain-belajar-bermain) terhadap kebugaran siswa SD di wilayah kecamatan tamansari kota Tasikmalaya. Penelitian ini menggunakan pendekatan kuantitatif dengan metode eksperimen, Populasi dalam penelitian ini yaitu siswa kelas V SD di wilayah kota Tasikmalaya tahun ajaran 2017/2018. Sampel diambil secara random sampling. Adapun analisis data yang diperoleh dari lapangan menggunakan perhitungan statistik berupa 1) uji normalitas 2) Uji t 3) Selisih gain. Hasil penelitian menunjukan play teach play mampu meningkatkan kebugaran siswa dengan selisih dari pre-test dan post test rata-rata $>50$ persen. Kesimpulan play teach play berpenngaruh terhadap peningkatan kebugaran jasmani siswa. Efektifitas play teach play dalam segi motivasi mengikuti pelajaran olahraga sangat meningkat.
\end{abstract}

Kata kunci:

Play teach play, kebugaran

\begin{abstract}
Abstrak
The problem in this study is the low fitness of elementary school students. This problem is due to the absence of a method of teaching sports that is in accordance with the development and characteristics of elementary students. Characteristics of elementary school children tend not to like the explanation of the theories and concepts of physical education teachers, they want fun learning. Fun learning can be done through the game method so that children are interested in continuing to move. The long-term goal of this study is to apply game methods in sports learning in elementary schools that support the optimal learning process of sports to improve fitness. While the specific objective is to get a real picture of the effectiveness of the play-teach-play method on the fitness of elementary students in the area of Tamansari sub-district in Tasikmalaya city. This study uses a quantitative approach to the experimental method, the population in this study is the fifth grade elementary school students in the city of Tasikmalaya in the academic year 2017/2018. Samples were taken by random sampling. The analysis of data obtained from the field using statistical calculations in the form of 1) normality test 2) $t$ test 3) Difference in gain. The results showed that play play play was able to improve students' fitness with the difference from the pre-test and post test on average $>50$ percent. The conclusion of play play play has an effect on improving students' physical fitness. The effectiveness of play teach play in terms of motivation to participate in sports lessons is greatly increased.
\end{abstract}

Keywords:

Play teach play, fitness 


\section{A. PENDAHULUAN}

Peningkatan kebugaran pada siswa Sekolah Dasar (SD) menjadi sangat penting karena siswa SD termasuk usia ideal untuk diberikan latihan-latihan kebugaran dasar dan penanaman hidup sehat dan bugar. Semakin bertambah usia seorang anak tentunya akan bertambah pula aktivitas fisiknya, maka diperlukan peningkatan fisik untuk melakukan segala aktivitas tanpa menimbulkan kelelahan. Menurut Muhajir (2007:5-7) "Kebugaran jasmani adalah kesanggupan dan kemampuan tubuh melakukan penyesuaian (adaptasi) terhadap pembebanan fisik yang diberikan kepadanya dari kerja yang dilakukan seharihari tanpa menimbulkan kelelahan yang berlebihan".

Ada beberapa faktor yang mempengaruhi kebugaran jasmani, salah satunya adalah kebiasaan olahraga. Olahraga adalah suatu kegiatan fisik menurut cara dan aturan tertentu dengan tujuan meningkatkan efisiensi fungsi tubuh yang hasil akhirnya adalah untuk meningkatkan kebugaran jasmani. Menurut Mahardika, (2010:87) "kebugaran jasmani mengandung pengertian bagaimana kemampuan jasmani seseorang dalam melakukan tugas kejasmanian sehari-hari secara optimal bahkan masih dapat melakukan kegiatan jasmani tambahan lainnya tanpa menimbulkan kelelahan yang berarti”.

Kemampuan tubuh untuk melakukan adaptasi pada aktivitas yang lebih berat diperlukan proses latihan-latihan fisik. Latihan fisik untuk siswa didapat melalui mata pelajaran Pendidikan Jasmani, Olahraga dan Kesehatan (PJOK). Penanaman hidup sehat dan bugar ada dalam kurikulum PJOK. Pendidikan jasmani pada hakikatnya adalah proses pendidikan yang memanfaatkan aktivitas fisik untuk menghasilkan perubahan holistik dalam kualitas individu, baik dalam hal fisik, mental serta emosional. Pendidikan jasmani adalah suatu bidang kajian yang berkaitan dengan gerak manusia, perkembangan fisik dan psikis
(Hartono, dkk. 2013: 2). Akan tetapi keberhasilan pembelajaran PJOK ditentukan oleh guru olahraga yang menerapkan metode mengajar yang sesuai untuk peserta didik.

Nurhasan (2005:1): "Untuk mewujudkan manusia Indonesia seutuhnya salah satunya melalui pendidikan jasmani, olahraga, dan kesehatan (PJOK)". Pelaksanaan PJOK merupakan mata pelajaran yang sangat berperan dalam peningkatkan kebugaran jasmani siswa. Rendahnya tingkat kebugaran jasmani dapat disebabkan kurangnya gerak remaja masa kini. Untuk itu PJOK dapat dijadikan sarana untuk memperbaiki dan membina tingkat kebugaran jasmani, selain untuk mencapai hidup yang sehat.

Metode pengajaran PJOK yang tidak sesuai akan berdampak pada penurunan kebugaran jasmani. Karakteristik siswa SD identik dengan bermain (Play) karena secara alami anak merupakan individu yang ingin selalu mendapatkan kegembiraan dan kesenangan. Menurut Hartati et al. (2012:3) "Mengatakan bermain adalah kegiatan yang digunakan oleh anak untuk melupakan ekspresi, pelampiasan, ketegangan dan menirukan peran orang yang ia kagumi atau yang ia jadikan guru". Jadi dengan kata lain bermain itu aktivitas yang penuh dengan nuansa keriangan yang memiliki tujuan yang melekat didalamnya untuk kegembiraan dan kesenangan. Oleh karena itu mata pelajaran PJOK di SD memerlukan pendekatan dan metode permainan untuk peningkatan kebugaran dan minat berolahraga.

Permasalahan dilapangan menitikberatkan pada metode mengajar PJOK, penulis dan tim telah melakukan observasi di tiga SD wilayah Kecamatan Tamansari kota Tasikmalaya. Rata-rata guru olahraga masih melakukan metode pengajaran konvensional (biasa). Pengajaran konvensional yang dilakukan dari mulai tahap pertama yaitu pemanasan yang hanya lari berkeliling lapangan dan melakuan lalihan kekuatan seperti 
push up, sit up dan squat jump. Kegiatan lari yang monoton berpotensi menimbulkan rasa bosan dan berdampak pada minat berolahraga sedangkan latihan kekuatan dirasa kurang sesuai untuk siswa SD. Sehingga anak cenderung akan melakukan olahraga secara terpaksa. Sejalan Djaali (2008: 121) "Minat adalah rasa lebih suka dan rasa ketertarikan pada suatu hal atau aktivitas, tanpa ada yang menyuruh".

Setelah tahap pemanasan selesai dilanjutkan dengan tahap kedua yaitu inti. Pada tahapan ini pembelajaran dilakukan dengan cara berpusat pada guru (teacher center). Anak hanya mengikuti seluruh instruksi dari guru tanpa diberi kesempatan untuk mengeksplorasi gerak sehingga berpikir kreatif (creative thinking) akan terkunci. Tahapan ketiga ialah pendinginan, pada tahapan ini guru hanya menyuruh anak berbaris untuk melakukan pelemasan sesuai intruksi. Tidak adanya inovasi bermain dalam melakukan proses penutupan belajar. Sehingga hasil dari belajar PJOK cenderung tidak bermakna bagi peserta didik yang hanya sekedar berkeringat.

Hasil observasi dari ketiga tahapan pembelajaran PJOK tersebut belum terdapat pengajaran yang sesuai dengan kemampuan dan karakteristik anak usia SD yang cenderung senang bermain. Menurut Suhermen (2009:12): "Developmentally appropriate practice (DAP) adalah program-program latihan atau aktivitas gerak yang diberikan harus sesuai dengan kemampuan gerak anak didik yang sedang belajarnya". Maka guru harus mampu mengakomodasi setiap perbedaan karakteristik dan perubahan kapasitas gerak ke arah yang lebih baik dengan menerapkan metode yang sesuai.

Salah satu metode pengajaran PJOK yang dirasa sesuai dengan karakteristik siswa SD ialah metode play-teach-play (bermaininstruksi-bermain). Menurut Suherman (2009:117): Menjelaskan beberapa keuntungan dari teknik "play-teach-play", yaitu:
1. Dapat meningkatkan minat siswa untuk melakukannya karena bermain (play) selalu dimninati siswa. Sementara itu, latihan dapat juga dilakukan melalui bermain (play) yang dianggap siswa sebagai main-main. Ibarat bola yang kempes (gembos), udara diibaratkan sebagai play untuk mengisi bola yang gembos sehingga menjadi keras kembali. Setelah minat siswa cukup tinggi, intruksi (teach) diberikan, dan setelah gembos, berikkutnya diberikan play lagi, demikian seterusnya.

2. Siswa latihan dalam suasana permainan yang sebenarnya. Dalam kesempatan tersebut siswa akan menemukan berbagai masalah yang dapat menimbulkan minat belajar yang lebih tinggi lagi. Kesempatan tersebut bisa dimanfaatkan oleh guru untuk melatihnya lebih baik lagi. Keadaan ini memungkinkan PBM berlangsung lebih efektif. Siswa merasakan adanya keinginan untuk belajar keterampilan yang diberikan oleh gurunya.

Dari pernyataan tersebut menegaskan bahwa play-teach-play dirasa mampu meningkatkan kualitas belajar mengajar PJOK untuk siswa jenjang SD. Kesimpulan hasil penelitian terdahulu oleh Risyanto (2015:83): Menunjukkan bahwa terdapat pengaruh positif antara pendekatan pembelajaran "play-teachplay" terhadap peningkatan motivasi belajar siswa dan hasil belajar pendidikan jasmani. Berdasarkan hasil penelitian, pendekatan pembelajaran "play-teach-play" lebih baik daripada pendekatan pembelajaran konvensional terlihat dari tingkat motivasi belajar siswa dan hasil belajar pendidikan jasmani. Maka dapat disimpulkan bahwa kelas eksperiment lebih besar tingkat motivasi belajar dan hasil belajarnya dibandingkan kelas kontrol. Akan tetapi belum dilakukan pembuktian seberapa besar efektivitasnya terhadap peningkatan kebugaran dan minat berolahraga para peserta didik. 


\section{Teori}

Play-teach-play secara bahasa artinya bermain-mengajar-bermain. Merupakan bagian dari metode mengajar dalam pendidikan jasmani. Metode ini digunakan ketika karakteristik siswa tidak senang mendengar penjelasan konsep dari gurunya, tidak senang latihan untuk meningkatkan keterampilan dan sulit focus terhadap materi yang diberikan. Sesuai pendapat Graham (2008:93): 'As you might expect, children don't want to listen to long explanation. They want to be active. Its hard for them to make the connection between practice today and profiency several years from now. They want to play not practice. In addition to pinpointing and checking for understanding, another effective technique is a part of instruction and demonstration process is playteach-play'.

Karakteristik siswa SD identik dengan kegiatan bermain (play) sehingga kegiatan belajar mengajar perlu disesuaikan dari mulai kemampuan gerak, prilaku dan keinginan. Dengan menerapkan konsep bermain diharapkan peningkatan minat berolahraga akan tercapai sehingga berdampak pada level kebugaran. Suherman (2009:117) mengungkapkan keuntungan dari penerapan play-teach-play sebagai berikut:

1. Dapat meningkatkan minat siswa untuk melakukannya karena bermain (play) selalu dimninati siswa. Sementara itu, latihan dapat juga dilakukan melalui bermain (play) yang dianggap siswa sebagai main-main. Ibarat bola yang kempes (gembos), udara diibaratkan sebagai play untuk mengisi bola yang gembos sehingga menjadi keras kembali. Setelah minat siswa cukup tinggi, intruksi (teach) diberikan, dan setelah gembos, berikkutnya diberikan play lagi, demikian seterusnya.

2. Siswa latihan dalam suasana permainan yang sebenarnya. Dalam kesempatan tersebut siswa akan menemukan berbagai masalah yang dapat menimbulkan minat belajar yang lebih tinggi lagi. Kesempatan tersebut bisa dimanfaatkan oleh guru untuk melatihnya lebih baik lagi. Keadaan ini memungkinkan PBM berlangsung lebih efektif. Siswa merasakan adanya keinginan untuk belajar keterampilan yang diberikan oleh gurunya.

Salah satu riset yang telah dilakukan yaitu berfokus pada bagaimana metode play-teachplay memberikan pengaruh terhadap motivasi belajar dan hasil belajar pendidikan jasmani. Temuan dari dari hasil penelitian, menunjukkan bahwa terdapat pengaruh positif antara pendekatan pembelajaran "play-teach-play" terhadap peningkatan motivasi belajar siswa dan hasil belajar pendidikan jasmani (Risyanto,2015:19). Ini menunjukan bahwa motivasi belajar olahraga akan terbentuk manakala metode yang dilakukan sangat menarik perhatian anak sehingga hasil belajar olahraga akan tercapai.

Pengajaran olahraga dengan konsep bermain ternyata mampu memberikan dampak yang sangat besar terhadap perkembangan skill. Zhang, ward,li .et al. (2012:71-85) dengan topik menguji perbandingan latihan melalui permainan (Play Practice) dan latihan yang berfokus pada keterampilan (Skill focused Instruction). Hasil penelitian menunjukkan bahwa play practice maupun skill focused efektif dalam meningkatkan kemampuan siswa dalam teknik forehand drive, forehand attack, dan serve dari hasil pre-test dan posttest. Namun, play practice sangat efektif dalam meningkatkan kemampuan siswa dalam forehand attack dan serve dibandingkan dengan skill focus.

\section{Kebugaran}

Kebugaran dapat diartikan ketika seseorang melakukan kegiatan fisik secara 
berulang-berulang tetapi tidak mengalami kelelahan berlebihan. Menurut Mahardika (2010:87) "kebugaran jasmani mengandung pengertian bagaimana kemampuan jasmani seseorang dalam melakukan tugas kejasmanian sehari-hari secara optimal bahkan masih dapat melakukan kegiatan jasmani tambahan lainnya tanpa menimbulkan kelelahan yang berarti". Maka ketika seseorang tidak kelelahan dalam melakukan aktifitas kerja harian dapat dikatakan level kebugaranya tinggi.

Lebih lanjut menurut Muhajir (2007:5): "Kebugaran jasmani adalah kesanggupan dan kemampuan tubuh melakukan penyesuaian (adaptasi) terhadap pembebasan fisik yang diberikan kepadanya (dari kerja yang 20 dilakukan sehari-hari) tanpa menimbulkan kelelahan yang berlebihan".

Derajat kebugaran siswa dapat diraih dengan melakukan olahraga pada kegiatan pembelajaran pendidikan jasmani. Khusus olahraga kesehatan hendaknya dijadikan sebagai materi pokok dalam pelaksanaan pembinaan mutu siswa melalui pendekatan jasmaniahnya. Giriwijoyo (2012:26): "Olahraga kesehatan adalah olahraga untuk memelihara dan/atau untuk meningkatkan derajat kesehatan dinamis, sehingga orang bukan saja sehat dikala diam tetapi juga sehat ketika bergerak".

Hubungan antara kebugaran jasmani dan mental (psikis) pada anak usia SD sangat erat kaitanya dengan kesejahteraan psikologis. Dalam penelitian Lavigne (2016:32-47) menguji tentang hubungan antara kebugaran jasmani dengan tiga aspek kesejahteraan (gejala depresi, kesepian dan kompetensi) pada anak usia 10-14 tahun. Hasil menunjukan anak dengan tingkat kebugaran jasmani yang lebih tinggi mempunyai tingkat gejala depresi dan kesepian yang lebih rendah sedangkan kompetensi kognitif, social, keterampilan lebih tinggi. Maka tingkat kebugaran jasmani usia anak SD sangat penting untuk ditingkatkan dengan metode mengajar yang sesuai karakteristik siswa.

\section{METODE}

\section{Tahapan Penelitian}

Dalam menetapkan tahapan penelitian penulis perlu menyesuaikan dengan desain yang digunakan. Dalam penelitian ini digunakan desain eksperimen. Ali (2011:271): 'Agar diperoleh hasil yang optimal ditempuh langkah-langkah penelitian sebagai berikut:

1. Meneliti berbagai literatur yang berhubungan dengan masalah riset

2. Mengidentifikasi, merumuskan dan mengelaborasi rumusan masalah

3. Merumuskan hipotesis

4. Menyusun rencana secara lengkap dan operasional, meliputi:

1) Menentukan variabel bebas dan variabel terikat

2) Memilih desain yang akan digunakan

3) Memilih subyek yang dijadikan sampel secara random

4) Mengembangkan instrument pengukuran atau memilih instrument pengukuran yang baku

5) Membuat rencana pokok dan langkahlangkah dalam melakukan eskperimen dan pengumpulan data

6) Merumuskan hipotesis statistic berdasarkan rumusan hipotesis riset

5. Melaksanakan eksperimen

6. Menyeleksi dan menyusun data untuk memudahkan analisis

7. Menentukan taraf signifikansi yang akan digunakan dalam menguji hipotesis

8. Menganalisis data deng metode statistiak yang relevan (menguji hipotesis berdasarkan data yang terkumpul

\section{Lokasi Penelitian}

Lokasi penelitian dilaksanakan di delapan Sekolah Dasar yang berada di wilayah kecamatan tamansari kota Tasikmalaya. Yaitu SDN Gobras, SD Tamansari, SD Islam Alazhar 33, SD IT Al-Muslimin, SD Setia mulya, SD Tirtayasa,SD Panunggulan dan SD Sangkali.

\section{Peubah yang diamati}


Penelitian ini memiliki tiga variabel, yaitu Efektivitas metode Play-teach-play sebagai varibel bebas (X) dan Peningkatan kebugaran dan minat berolahraga sebagai variabel terikat $(\mathrm{Y})$.

Agar ketiga variabel yang akan diteliti dapat dipahami dan sebagai upaya untuk menghindari kesalahpahaman dalam menafsirkan variabel yang dimaksud, berikut ini diuraikan definisi operasional variabel yang diteliti.

\section{Instrumen Penelitian}

Instrumen penelitian yang digunakan berdasarkan definisi operasional pada setiap variabel yang diamati. Pertama, instrumen berupa tes untuk mengetahui tingkat kebugaran jasmani usia 10-12 tahun menggunakan Tes Kesegaran Jasmani Indonesia yang sering kita dengar sebagai tes TKJI merupakan tes yang telah disepakati menjadi instrumen atau sebagai alat tes di indonesia, karena tes ini disusun dan disesuaikan dengan kemampuan orang indonesia dan disusun juga berdasarkan pembagian umur (Nurhasan, 2013:63). Adapun komponen TKJI untuk usia 10-12 tahun dapat dilihat dari tabel 2.

Tabel 1

Komponen TKJI Usia 10-12 Tahun

Permana (2016:4)

\begin{tabular}{|c|l|}
\hline No & \multicolumn{1}{|c|}{ Komponen Tes } \\
\hline 1 & Lari Cepat (Sprint) \\
\hline 2 & Angkat tubuh (pull up) \\
\hline 3 & Baring Duduk (Sit Up) \\
\hline 4 & Loncat Tegak (Vertical Jump) \\
\hline
\end{tabular}

\section{A. Rancangan Penelitian}

Desain dalam penelitian ini menggunakan pendekatan penelitian kuantitatif. Creswell (2012) menjelaskan bahwa pendekatan kuantitatif dipilih sebagai pendekatan penelitian ketika tujuan penelitian sebagai berikut: menguji teori; mengungkapkan fakta-fakta; menunjukkan hubungan antar variabel; dan memberikan deskripsi. Metode yang dipergunakan dalam penelitian ini adalah metode eksperimen murni (true experiment).

Populasi dan sampel dalam penelitian ini adalah siswa SD kelas lima di wilayah kecamatan tamansari kota Tasikmalaya berjumlah 20 SD. Teknik pengambilan sampel menggunakan simple random sampling. Creswell (2012) menyatakan simple random sampling merupakan bentuk paling populer dan ketat dalam probability sampling. Dalam prosedur ini, pengambilan sampel penelitian dilakukan dengan menggunakan teknik simple random sampling. Maka menghasilkan lima SD sebagai kelompok kontrol dan lima SD sebagai kelompok eksperimen.

Teknik Pengumpulan Data

Teknik pengumpulan data dalam penelitian ini yang dilaksanakan sebelum dan sesudah perlakuan. Teknik pengumpulan berupa tes kebugaran jasmani Indonesia (TKJI) sesuai kriteria baku yang telah dipaparkan pada model instrument penelitian. Tujuan TKJI ialah untuk mengetahui tingkat kebugaran jasmani siswa.

\section{Analisis Data}

Dalam penelitian ini analisis dilakukan dengan cara mengitung gain atau selisih hasil dari pre-test dan post-test. Kemudian selisih ini dianalisis normalitasnya. Pengujian dibantu oleh program SPSS Ibm versi 20 menggunakahn uji normalitas Kolmogorov smirnov sampai pada uji t paired sample t test.

\section{B. HASIL DAN PEMBAHASAN \\ 1. Hasil}

Hasil rata-rata tes kebugaran jasmani Indonesia, data pre-test dan post test setelah dikonversikan pada norma standar penilaian TKJI untuk masing-masing skor (Nurhasan:2013)

Tabel 1. Lari cepat $40 \mathrm{M}$

\begin{tabular}{l|l|l|l|}
\hline Sekolah & Rerata Pre-tes & Rerata post-tes & Selisih \\
\hline
\end{tabular}




\begin{tabular}{|c|l|c|c|c|}
\hline 1 & SDIT Al-Muslimin & 2.3 & 4 & 1.7 \\
\hline 2 & SDN 2 Gobras & 2.5 & 3.9 & 1.4 \\
\hline 3 & SDN Cisengkol & 2.2 & 4.1 & 1.9 \\
\hline 4 & SDN 2 Sukamulya & 2.4 & 4.2 & 1.8 \\
\hline 5 & SDN Sangkali & 2.3 & 4.3 & 2 \\
\hline
\end{tabular}

Tabel 2. Pull Up

\begin{tabular}{|c|l|c|c|c|}
\hline No & \multicolumn{1}{|c|}{ Sekolah } & Rerata Pre-tes & Rerata post-tes & Selisih \\
\hline 1 & SDIT Al-Muslimin & 2 & 3 & 1 \\
\hline 2 & SDN 2 Gobras & 1.5 & 3 & 1.5 \\
\hline 3 & SDN Cisengkol & 1.8 & 3.7 & 1.9 \\
\hline 4 & SDN 2 Sukamulya & 2 & 3.4 & 1.6 \\
\hline 5 & SDN Sangkali & 2.1 & 3.2 & 1.1 \\
\hline
\end{tabular}

Tabel 3.Sit Up

\begin{tabular}{|c|l|c|c|c|}
\hline No & \multicolumn{1}{|c|}{ Sekolah } & Rerata Pre-tes & Rerata post-tes & Selisih \\
\hline 1 & SDIT Al-Muslimin & 3 & 5 & 2 \\
\hline 2 & SDN 2 Gobras & 3.5 & 4.8 & 1.3 \\
\hline 3 & SDN Cisengkol & 3 & 4.7 & 1.4 \\
\hline 4 & SDN 2 Sukamulya & 3 & 5 & 2 \\
\hline 5 & SDN Sangkali & 3.1 & 5 & 1.9 \\
\hline
\end{tabular}

Tabel. 4 Loncat Tegak

\begin{tabular}{|c|l|c|c|c|}
\hline No & \multicolumn{1}{|c|}{ Sekolah } & Rerata Pre-tes & Rerata post-tes & Selisih \\
\hline 1 & SDIT Al-Muslimin & 2 & 4 & 2 \\
\hline 2 & SDN 2 Gobras & 2 & 4.5 & 2.5 \\
\hline 3 & SDN Cisengkol & 2.8 & 5 & 2.2 \\
\hline 4 & SDN 2 Sukamulya & 2 & 4 & 2 \\
\hline 5 & SDN Sangkali & 2.1 & 4 & 1.9 \\
\hline
\end{tabular}

Tabel 5. Tes lari jarak sedang

\begin{tabular}{|c|l|c|c|c|}
\hline No & \multicolumn{1}{|c|}{ Sekolah } & Rerata Pre-tes & Rerata post-tes & Selisih \\
\hline 1 & SDIT Al-Muslimin & 3 & 5 & 2 \\
\hline 2 & SDN 2 Gobras & 3.5 & 4.8 & 1.3 \\
\hline 3 & SDN Cisengkol & 3 & 4.7 & 1.4 \\
\hline 4 & SDN 2 Sukamulya & 3 & 5 & 2 \\
\hline 5 & SDN Sangkali & 3.1 & 5 & 1.9 \\
\hline
\end{tabular}

Tabel 5. Hasil Tes kesegaran Jasmani berdasarkan post test

\begin{tabular}{|c|l|c|c|c|c|c|}
\hline No & $\begin{array}{c}\text { Butir } \\
\text { Tes }\end{array}$ & $\begin{array}{c}\text { SDIT al- } \\
\text { muslimin }\end{array}$ & $\begin{array}{c}\text { SDN 2 } \\
\text { Gobras }\end{array}$ & $\begin{array}{c}\text { SDN } \\
\text { Cisengkol }\end{array}$ & $\begin{array}{c}\text { SDN 2 } \\
\text { Sukamulya }\end{array}$ & $\begin{array}{c}\text { SDN } \\
\text { Sangkali }\end{array}$ \\
\hline 1 & Sprint & 4 & 3.9 & 4.1 & 4.2 & 4.2 \\
\hline 2 & Pull up & 3 & 3 & 3.7 & 3.4 & 3.2 \\
\hline 3 & Sit up & 5 & 4.8 & 4.7 & 5 & 4 \\
\hline
\end{tabular}




\begin{tabular}{|c|l|c|c|c|c|c|}
\hline 4 & $\begin{array}{l}\text { Loncat } \\
\text { tegak }\end{array}$ & 4 & 4.5 & 4.5 & 4 & 5 \\
\hline 5 & $\begin{array}{l}\text { Lari } \\
\text { Jarak } \\
\text { Sedang }\end{array}$ & 5 & 4.8 & 4.7 & 5 & 5 \\
\hline & Jumlah & 21 & 21 & 21.1 & 21.6 & 21.4 \\
\hline & Kategori & Baik & Baik & baik & Baik & Baik \\
\hline
\end{tabular}

\section{Pembahasan}

Metode play teach play diberikan selama satu semester, dampak yang terjadi setelah pemberian perlakuan ialah siswa menjadi lebih termotivasi untuk melaksanakan tugas gerak yang diinstruksikan guru. Instruksi guru berupa permainan gerak yang menyenangkan seperti petak umpet, gobag sodor, Tarik tambang, kucing-kucingan, permainan ketangkasan dan lomba-lomba yang edukatif. Permainan diberikan sebelum masuk pada inti pembelajaran sesuai yang ada pada kurikulum pendidikan jasmani tahun 2013.

Pada aspek kebugaran, karena siswa aktif maka terjadi peningkatan yang signifikan terutama pada tes lari cepat dan baring duduk. Semua kategori tes dikatakan baik. Kaitanya dengan lari cepat dan lari sedang sangat efektifitas play teach play sangat dominan. Kedua tes ini menekankan pada aspek latihan aerobik atau daya tahan. Terlebih di setiap permainan banyak sekali gerakan-gerakan latihan daya tahan. Sehingga tes pull up kenaikanya tidak terlalu signifikan.

Kasus ini perlu menjadi perhatian peneliti untuk meneliti lebih lanjut tentang permainan gerak yang menitikberatkan pada aspek kekuatan. Sehingga siswa pada saat tes kebugaran sit up dan pull up lebih meningkat.

Kebugaran ditentukan juga oleh seberapa besar minat berolahraga siswa diluar pelajaran olahraga. Ada beberapa siswa yang mengikuti ekstrakurikuler sehingga dengan sendirinya kebugranya memang sudah baik. Adapun siswa yang tidak mengikuti ekstrakurikuler akan tetapi yang bersangkutan rutin melakukan aktivitas fisik bersama keluarga diliaur jam sekolah. Maka kedepan untuk perhatian para peneliti ketepatan pengambilan populasi dan sampel harus diperhatikan, sehingga sampel homogen. Dengan sampel homogen akan meminimalisir bias hasil dari tes kebugaran jasmani. Sehingga hasilnya akan lebih efektif untuk siswa.

\section{SIMPULAN}

Berdasarkan hasil dan pembahasan dapat ditarik kesimpulan selama satu semester. pemberian perlakuan tentang metode paly teach play terhadap peningkatan kebugaran dapat disimpulkan bahwa :

1. Terdapat pengaruh terhadap kebugaran jasmani dengan pemberian metode play teach play.

2. Play teach play efektif dalam meningkatkan kebugaran jasmani siswa.

3. Play teach play berkontribusi meningkatkan motivasi siswa untuk mengikuti pelajaran olahraga.

\section{Daftar Pustaka}

Ali, Mohammad. (2011). Memahami Riset Prilaku dan Sosila. Bandug. CV. Pustaka Cendekia Utama

Creswell, W. John. (2012). Educational Research: Planning, Conducting, and Evaluating Quantitative and Qualitative Research (Third Edition). New Jersey: Pearson Prentice Hall.

Giriwijoyo, Santosa. (2012). Ilmu Kesehatan Olahraga. Bandung. PT. Remaja Rosda Karya 
Graham, George. (2008). Teaching children physical education: becoming a master teacher $3^{\text {rd }}$ edition. United states. Human kinetics publisher

Hartati, Sasminta. (2013). Permainan Kecil (Cara Efektif Mengembangkan Fisik, Motorik, Keterampilan Sosial, dan Emosional). Malang: Wineka Media.

Hartono, Soetanto, dkk. (2013). Pendidikan Jasmani (Sebuah Pengantar). Surabaya: Unesa University Press.

Lavigne, Timothy. (2016). Associations between Physical Fitness and Children's Psychological Well-Being. Journal Of Clinical Sport Psychology. Volume: 10 Issue: 1 Pages: 32-47

Mahardika, I Made Sriundy. (2010). Pengantar Evaluasi Pengajaran. Surabaya : Unesa university Press

Muhajir. (2007). Pendidikan Jasmani, Kesehatan dan Rekreasi. Bandung: Yudhistira

Nurhasan dkk. (2005). Petunjuk Praktis Pendidikan Jasmani. Unesa : University Press.
Permana, Rahmat. (2016). Penguasaan Tes Kesegaran Jasmani (TKJI) melalui Diskusi dan Simulasi. Journal Refleksi Edukatika. Vol. 6 No. 2 Halaman 7178

Risyanto, Aris. (2014). Pengaruh Pendekatan Pembelajaran "Play-Teach-Play" Terhadap Peningkatan Motivasi Belajar Siswa dan Hasil Belajar Pendidikan Jasmani. S2 Thesis. Bandug. repository.upi.edu.

Slameto, (2010). Belajar dan Faktor-Faktor Yang Mempengaruhinya. Edisi revisi. Jakarta. Rineka cipta

Soemitro. (1992). Permainan Kecil. Jakarta: Direktorat Jendral Perguruan Tinggi.

Suherman, Adang. (2009). Revitalisasi Pengajaran dalam Pendidikan Jasmani. Bandung. CV. Bintang Warli Artika

Zhang, Ward, Li, Shuterland \& Goodway. (2012). Effects of Play Practice on Teaching Table Tennis Skills. Journal Of Teaching In Physical Education. Volume:31 Issue: 1 Pages:71-85 